\title{
Metaxin deficiency alters mitochondrial membrane permeability and leads to resistance to TNF-induced cell killing
}

\author{
Koh Ono', Xiaofei Wang1, Sung Ouk Kim¹, Lucas C. Armstrong ${ }^{2}$, Paul Bornstein², \\ Jiahuai $\operatorname{Han}^{1}(\bowtie)$ \\ ${ }^{1}$ Department of Immunology and Microbial Science, The Scripps Research Institute, La Jolla, \\ CA 92037, USA \\ 2 Department of Biochemistry, University of Washington, Seattle, WA 98195-7350, USA \\ $\triangle$ Correspondence: jhan@scripps.edu
}

Received December 1, 2009; accepted December 10, 2009

\section{ABSTRACT}

Metaxin, a mitochondrial outer membrane protein, is critical for TNF-induced cell death in L929 cells. Its deficiency, caused by retroviral insertion-mediated mutagenesis, renders L929 cells resistance to TNF killing. In this study, we further characterized metaxin deficiency-caused TNF resistance in parallel with $\mathrm{Bcl}-\mathrm{X}_{\mathrm{L}}$ overexpressionmediated death resistance. We did not find obvious change in mitochondria membrane potential in metaxindeficient (Met ${ }^{\text {mut }}$ ) and $\mathrm{Bcl}-\mathrm{X}_{\mathrm{L}}$-overexpressing cells, but we did find an increase in the release rate of the mitochondrial membrane potential probe rhodamine 123 (Rh123) that was preloaded into mitochondria. In addition, overexpression of a function-interfering mutant of metaxin (Meta $\Delta \mathrm{TM} / \mathrm{C}$ ) or $\mathrm{Bcl}-\mathrm{X}_{\mathrm{L}}$ in MCF-7.3.28 cells also resulted in an acquired resistance to TNF killing and a faster rate of Rh123 release, indicating a close correlation between TNF resistance and higher rates of the dye release from the mitochondria. The release of Rh123 can be controlled by the mitochondrial membrane permeability transition (PT) pore, as targeting an inner membrane component of the PT pore by cyclosporin A (CsA) inhibited Rh123 release. However, metaxin deficiency and $B c l-X_{L}$ overexpression apparently affect $R$ h123 release from a site(s) different from that of CsA, as CsA can overcome their effect. Though both metaxin and $\mathrm{Bcl}-\mathrm{X}_{\mathrm{L}}$ appear to function on the outer mitochondrial membrane, they do not interact with each other. They may use different mechanisms to increase the permeability of Rh123, since previous studies have suggested that metaxin may influence certain outer membrane porins while $\mathrm{Bcl}-\mathrm{X}_{\mathrm{L}}$ may form pores on the outer membrane. The alteration of the mitochondrial outer membrane properties by metaxin deficiency and Bcl- $\mathrm{X}_{\mathrm{L}}$ overespression, as indicated by a quicker Rh123 release, may be helpful in maintaining mitochondrial integrity.

KEYWORDS metaxin, apoptosis, necrosis, mitochondria

\section{INTRODUCTION}

Tumor necrosis factor- $\alpha$ (TNF) is a pro-inflammatory cytokine that acts as a mediator of host defense against both neoplasia and infection (Carswell et al., 1975; Old, 1985; Beutler and Cerami, 1986, 1988; Rothe et al., 1992; Tartaglia and Goeddel, 1992; Tracey and Cerami, 1993). Along with its beneficial roles in immune regulation, TNF has been implicated in the pathogenesis of both acute and chronic inflammatory diseases (Beutler and Cerami, 1988). TNF induces cell death in numerous cell lines (Old, 1985; Beutler and Cerami, 1988; Tartaglia et al., 1993; Tewari and Dixit, 1995; Fiers et al., 1999; Li and Yuan, 1999). The morphological characteristics of the response differ markedly between TNF-treated cell lines: KYM, MCF-7 and PC60 tumor lines die apoptotically in response to TNF-treatment (Tewari and Dixit, 1995), whereas L929 and WEHI 164 clone 13 cells die necrotically (Beyaert and Fiers, 1994; Fiers et al., 1999). TNFinduced apoptosis is caspase-dependent, but TNF-induced L929 cell death cannot be blocked by inhibition of caspases and is even enhanced by the caspase inhibitor zVAD (Vercammen et al., 1998). 
Both apoptosis and necrosis are initiated by TNF receptor I (TNF-RI) clustering (Tewari and Dixit, 1995). The clustered TNF-RI recruits the death domain (DD)-containing adaptor proteins (Boldin et al., 1996; Fiers et al., 1999; Strasser et al., 2000), which in turn stimulate caspase-8 autoactivation of the apoptosis pathway. Active caspase-8 is an initiator caspase that either acts via cytochrome c (Cyt c) release or by the direct activation of effector caspases to execute apoptosis (Goossens et al., 1995). Like apoptosis, the necrotic pathway in fibroblasts is also initiated by TNF-RI. Receptor interacting protein 1 (RIP1) was demonstrated to be required for TNFinduced apoptosis as well as necrosis (Holler et al., 2000; Lin et al., 2004). Recently, RIP3 was shown to be able to convert TNF-induced apoptosis to necrosis, and it was shown to be essential for necrosis in several different cell types (Cho et al., 2009; Galluzzi et al., 2009; He et al., 2009; Zhang et al., 2009). It is known that activation of pro-apoptotic caspases, including caspase-8, and Cyt c release are not required for necrosis (Vercammen et al., 1998; Fiers et al., 1999; Goossens et al., 1999), while the generation of TNFstimulated reactive oxygen species (ROS) in mitochondria is involved in necrosis (Neale et al., 1988; Brekke et al., 1992; Schulze-Osthoff et al., 1992; Goossens et al., 1995). It should be noted that ROS alone is not sufficient to cause necrosis, since cells survive very well when high levels of ROS (10-100 times more than TNF-treated cells) are induced by different stimuli (Goossens et al., 1999). Therefore, direct damage from ROS overproduction cannot be the sole driving force for TNF-induced necrosis. Some data suggest that alterations in mitochondrial properties are associated with both apoptosis and necrosis. The changes, such as mitochondrial membrane permeability transition (PT), could be very important in both type of cell death (Pastorino et al., 1996; Kroemer and Reed, 2000).

The proteins of the Bcl-2 family regulate cell death pathways (Adams and Cory, 1998; Lotem et al., 1999; Vander Heiden and Thompson, 1999). Overexpression of antiapoptotic $\mathrm{Bcl}-2$ family members can prevent both apoptosis and necrosis (Kroemer et al., 1998). Although the mechanisms by which anti-apoptotic Bcl-2 family members function remain unclear, several models have been proposed. One is a direct sequestration model in which anti-apoptotic $\mathrm{Bcl}-2$ family members directly sequester caspase activators. This model is supported by studies in C. elegans; however, there is no supporting data from mammalian cells currently (Adams and Cory, 1998). Another model is that Bcl-2 family members govern caspase activation indirectly through their effects on the mitochondria. Because overexpression of anti-apoptotic $\mathrm{Bcl}-2$ family proteins precludes all the mitochondrial changes that are associated with cell death, such as membrane permeability, these proteins may inhibit cell death by preventing the escape of the apoptogenic proteins that are harbored in the mitochondrial intermembrane space (Adams and Cory, 1998; Vander Heiden and Thompson, 1999).
Currently, the mechanism by which apoptogenic proteins are released from the mitochondria is still unclear. This release may be mediated by a specific translocation mechanism, or it can result from the rupture of the outer membrane of the mitochondria. The 3D structure of $\mathrm{Bcl}-\mathrm{X}_{\mathrm{L}}$ suggests that $\mathrm{Bcl}-2$ family proteins can also form pores in the mitochondrial membrane (Muchmore et al., 1996). Bcl-2 family members were suggested to interact with preexisting pores, such as the permeability transition pore (Marzo et al., 1998; Shimizu et al., 1999), which is believed to reside either in the inner membrane or across sites of contact between the inner and outer membranes. However, the available evidence is not conclusive as to whether $\mathrm{Bcl}-2$ family proteins form their own pores or modulate the function of other pores. Moreover, controversial evidence exists regarding whether opening or closing the pores has an anti-apoptotic effect (Shimizu et al., 1999; Vander Heiden et al., 2000).

We used a random gene disruption method to search for genes that are required for TNF-induced cell death (Ono et al., 2001; Wang et al., 2001). Metaxin is a protein that was identified by this genetic approach (Wang et al., 2001). Metaxin was first identified serendipitously in an attempt to establish a mouse model for Gaucher disease by introducing an A-to-G mutation into the glucocerebrosidase (GC) gene using homologous recombination (Bornstein et al., 1995). Because the metaxin gene is located close to the GC gene, it was disrupted by this approach, which resulted in the death of mice during early gestation. Metaxin is an outer mitochondrial membrane protein and has a certain degree of sequence similarity with Tom37, a receptor in the mitochondrial general import pore (GIP) found in yeast. GIP is a preproteinconducting channel of the outer mitochondrial membrane (Pfanner and Geissler, 2001). Recent data suggests that GIP may also be involved in metabolite transport across the outer membrane (Kmita and Budzinska, 2000; Antos et al., 2001). Metaxin may function as a receptor in the mammalian GIP, since anti-metaxin antibodies partially inhibit the uptake of preadrenodoxin into mitochondria in vitro (Armstrong et al., 1997). A mitochondrial location of metaxin is required for its function in TNF-induced cell death, as truncated metaxin that does not have a mitochondrial anchor sequence (Meta $\triangle T M / C$ ) functions as a dominant negative mutant to attenuate TNFinduced cell death (Wang et al., 2001). Here we further characterize the nature of metaxin-deficient cells and compare them with $\mathrm{Bcl}-\mathrm{X}_{\mathrm{L}}$ overexpressing cells. Although both metaxin and $\mathrm{Bcl}-\mathrm{X}_{\mathrm{L}}$ are mitochondrial outer membrane proteins, these two proteins did not directly interact with each other. Deficiency caused by viral insertion and impairment of endogenous wild-type metaxin by the interfering mutant Meta $\Delta T M / C$ or by the overexpression of $B c l-X_{L}$, all led to an acquired resistance to TNF-induced cell death in our experimental systems. Metaxin deficiency did not affect the mitochondrial membrane potential, but it did increase the rate of preloaded rhodamine $123(\mathrm{Rh} 123)$ release from mitochondria. 
A similar phenomenon was observed in $\mathrm{Bcl}-\mathrm{X}_{\mathrm{L}}$-overexpressing cells, and the quicker Rh123 release is associated with an acquired resistance to cells death. Therefore, mitochondrial membrane permeability seems to be altered in metaxindeficient cells, which may be the cause of their death resistance.

\section{RESULTS}

\section{Production of reactive oxygen species (ROS) is not altered in metaxin-deficient $L 929$ cells}

Our previous study showed that metaxin-deficiency in L929 fibroblasts resulted in resistance to TNF-induced cell death, which can be measured by either propidium iodide (PI) exclusion or annexin $V$ staining (Fig. $1 A$ and $1 B$ ). Since ROS production has been shown to play an important role in TNFinduced L929 cell death, we tested whether the TNF resistance in metaxin-deficient (Metamut) cells was related to the level of ROS production in L929 cells. Dihydrorhodamine 123 (DHR123) is a cell-permeable fluorogenic dye; oxidation of the non-fluorescent DHR123 by radical species yields the cationic fluorescent Rh123, which is subsequently sequestered by active mitochondria. Hence, the accumulation of Rh123 fluorescence in mitochondria reflects ROS levels. Parental and Meta ${ }^{\text {mut }}$ cells were treated with TNF for different periods of time and ROS production was measured by the oxidation of DHR123. As shown in Fig. 1C, TNFinduced ROS production in Metamut cells was comparable with that in parental cells, indicating that metaxin deficiency did not influence ROS production. To confirm that TNFinduced ROS production is the same in parental and Metamut cells, we measured the redox state of TNF-treated cells using hydroethidine (HE), which is often used to measure intracellular $\mathrm{O}_{2}^{-}$because it is oxidized to the fluorescent ethidium by $\mathrm{O}_{2}^{-}$. As shown in Fig. 1D, we did not observe any difference between parental and Metamut cells. We also measured ATP levels in parental and Meta ${ }^{\text {mut }}$ cells before and after TNF
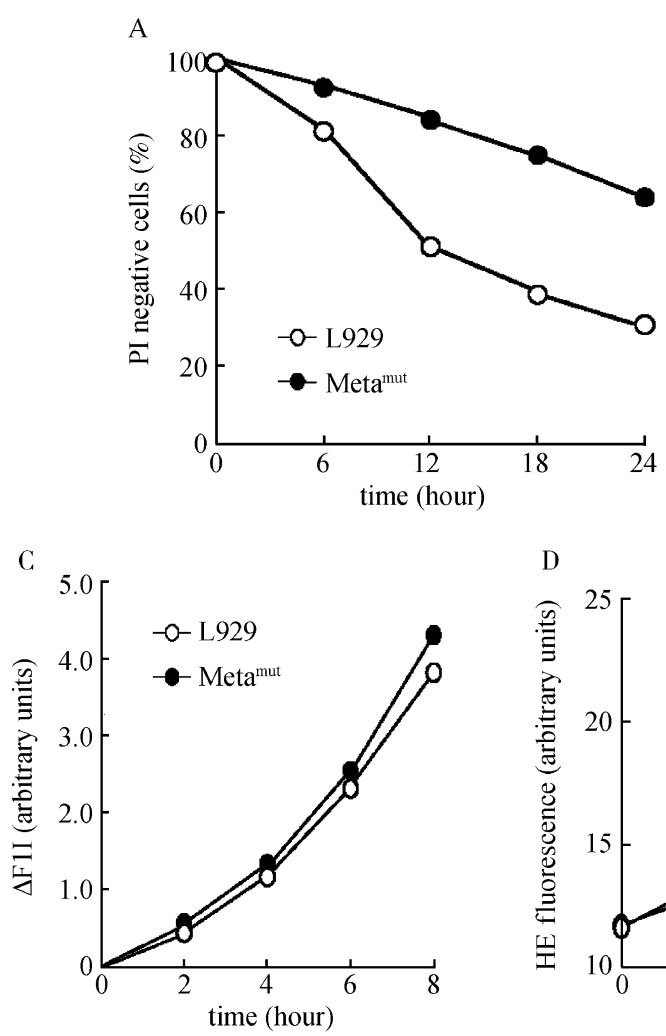

D

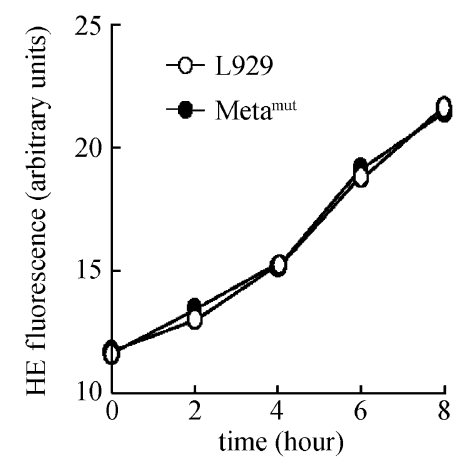

B

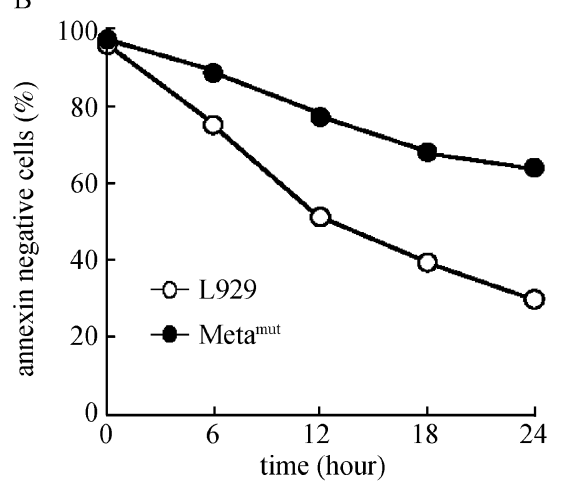

E

Figure 1. Metaxin deficiency does not affect oxidative phosphorylation. (A and B) Wild-type parental L929 cells (open circle), Meta $^{\text {mut }}$ cells (filled circle) were treated with TNF for different periods of time. Cell viability was measured by $\mathrm{PI}$ staining (A) or annexin V staining (B). (C) Flow cytometric (FACS) analyses of TNF-induced ROS production in parental and Metamut cells. ROS production was analyzed on the basis of TNF-induced DHR123 oxidation, which results in an increase in the mean Rh123 fluorescence intensity $(\Delta \mathrm{F} 1 \mathrm{l})$. Parental and Metamut cells were treated with TNF for different periods of time; PI negative cells (live cells) were gated and $\Delta F 1$ l was determined. (D) The same as (C) except that HE was used in the measurement. (E) Intracellular ATP levels were determined in parental and Metamut cells that were treated with TNF for different periods of time. 
stimulation, and there was no significant difference between these two cell lines (Fig. 1E). The slight reduction of the ATP levels in the later time points may result from the death of some cells. To confirm that the mitochondria were the major source of the measured ATP, we inhibited mitochondrial electron transport at complex III with antimycin A. Antimycin A significantly reduced ATP levels in both parental and Meta ${ }^{\text {mut }}$ cells, indicating that the ATP we measured is mainly generated in mitochondria (Fig. 1E). Therefore, metaxin deficiency did not affect oxidative phosphorylation in mitochondria.

\section{Both metaxin-deficiency and $\mathrm{Bcl}-\mathrm{X}_{\mathrm{L}}$ overexpression lead to an acquired resistance to TNF-induced cell death}

Since $\mathrm{Bcl}-\mathrm{X}_{\mathrm{L}}$ overexpression inhibits cell death in many cell systems, we compared TNF sensitivity in metaxin-deficient (Meta $^{\text {mut }}$ ) and Bcl- $\mathrm{X}_{\mathrm{L}}$-overexpressing $\mathrm{L} 929$ cells $\left(\mathrm{Bcl}-\mathrm{X}_{\mathrm{L}}\right)$. As shown in Fig. $2 \mathrm{~A}, \mathrm{Bcl}-\mathrm{X}_{\mathrm{L}}$ overexpression indeed inhibited TNF-induced L929 cell death. The level of inhibition caused by $\mathrm{Bcl}-\mathrm{X}_{\mathrm{L}}$ overexpression is similar to that of metaxin deficiency (Fig. 2A). Overexpression of Bcl- $X_{L}$ in Metamut cells did not further increase their resistance to TNF-induced

A

L929
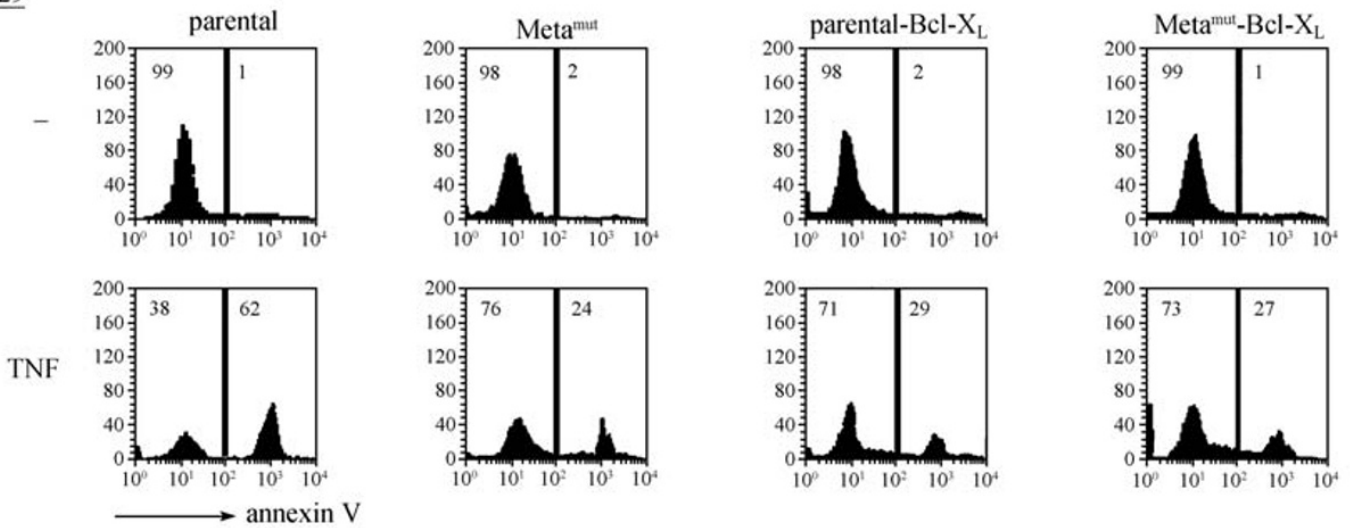

B

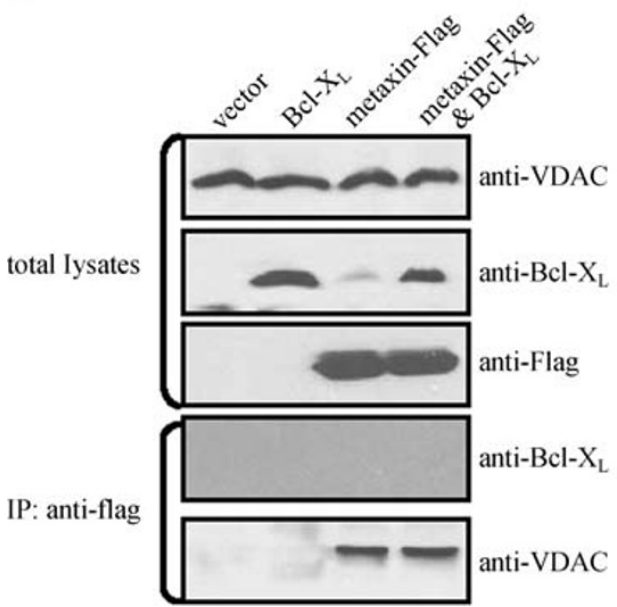

C MCF-7.3.28
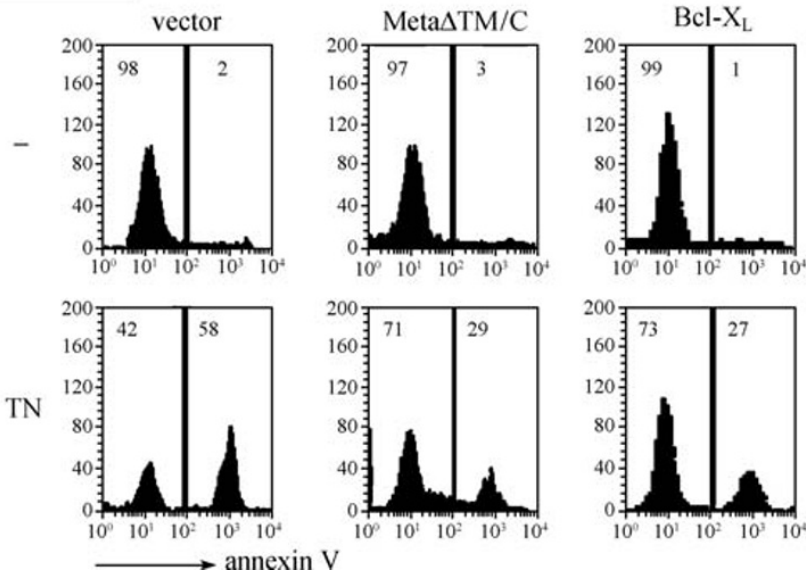

Figure 2. Metaxin deficiency and $\mathrm{Bcl}-\mathrm{X}_{\mathrm{L}}$ overexpression have similar effects on TNF-induced cell death, but these two proteins do not show direct interaction. (A) Parental cells, Metamut cells, parental cells transfected with $B c l-X_{L}$ (parental-Bcl- $X_{L}$ ), and Meta ${ }^{\text {mut }}$ cells transfected with Bcl- $\mathrm{X}_{\mathrm{L}}$ (Meta ${ }^{\text {mut }}-\mathrm{Bcl}-\mathrm{X}_{\mathrm{L}}$ ) were treated with TNF for $24 \mathrm{~h}$. The cells were then stained with annexin $\mathrm{V}$ and analyzed by flow cytometry. The cells were grouped into two regions according to their annexin-positive levels, and their percentage is shown inside each rectangular region. Metaxin deficiency and Bcl- $X_{L}$ overexpression inhibit TNF-induced cell death to a similar extent. Metaxin deficiency plus $\mathrm{Bcl}-\mathrm{X}_{\mathrm{L}}$ overexpression did not further enhance the cell survival. (B) 293 cells were transfected with expression vectors for $\mathrm{Bcl}-\mathrm{X}_{\mathrm{L}}$, Flag-metaxin, Flag-metaxin plus $\mathrm{Bcl}-\mathrm{X}_{\mathrm{L}}$, or empty pcDNA3 vector. pcDNA3 DNA was used to normalize the total DNA to $1 \mu \mathrm{g}$ per transfection. The cells were lysed $48 \mathrm{~h}$ after transfection and $1 / 3$ of each sample were analyzed directly by Western blotting to detect VDAC, Bcl- $X_{L}$ and Flag-metaxin. The rest of the cell lysates were immunoprecipitated with anti-Flag antibodies and then analyzed by Western blotting to detect $\mathrm{Bcl}-\mathrm{X}_{\mathrm{L}}$ and VDAC. Bcl- $\mathrm{X}_{\mathrm{L}}$ was not co-immunoprecipitated with metaxin. (C) MCF-7.3.28 cells transfected with empty vector (vector), a metaxin-interfering mutant containing the extramitochondrial domain (Meta $\triangle T M / C$ ), or Bcl- $\mathrm{X}_{\mathrm{L}}$, were all treated with TNF for $24 \mathrm{~h}$. Cell viability was analyzed by annexin $\mathrm{V}$ staining. Expression of either Meta $\triangle \mathrm{TM} / \mathrm{C}$ or Bcl- $\mathrm{X}_{\mathrm{L}}$ inhibited TNF-induced cell death. 
cell killing (Fig. 2A). The lack of an additive effect suggests that metaxin deficiency and $\mathrm{Bcl}-\mathrm{X}_{\mathrm{L}}$ overexpression cause the same effect on mitochondria. However, metaxin and Bcl- $X_{L}$ do not appear to interact directly with each other, since Bcl- $X_{L}$ could not be co-immunoprecipiated with metaxin when metaxin and Bcl- $X_{L}$ were coexpressed (Fig. 2B). By contrast, ecotopically expressed metaxin pulled down voltagedependent anion channel (VDAC), which is an outer mitochondrial membrane protein, confirming that the overexpressed metaxin was located on the outer mitochondria membrane. To compare the effects of the perturbation of endogenous metaxin and of $\mathrm{Bcl}-\mathrm{X}_{\mathrm{L}}$ overexpression in TNFinduced apoptosis, we used an MCF-7 line (MCF-7.3.28) that shows a typical apoptotic phenotype after TNF treatment (Janicke et al., 1998). MCF-7.3.28 cells were transfected with $\mathrm{Bcl}-\mathrm{X}_{\mathrm{L}}$ or with the metaxin cytosolic domain (Meta $\Delta T M / C$ ), which has previously been demonstrated to function in a dominant-negative fashion (Wang et al., 2001). TNF-induced cell killing was compared in these cell lines. As shown in Fig. 2C, interference with metaxin or overexpression of Bcl$X_{L}$ similarly inhibited TNF-induced cell death in MCF-7.3.28 cells.

One line of evidence for the involvement of PT in cell death is from the observation that CsA can attenuate cell death in a number of cell lines through the inhibition of the PT (Kroemer et al., 1998). Inhibition of TNF-induced L929 cell death by CsA has been reported and its mechanism is believed to be related to the PT (Pastorino et al., 1996). The PT pore is believed to be located across sites of contact between the inner and outer membranes, and to be formed by VDAC, cyclophilin D, and adenine nucleotide (ADP/ATP) translocases (ANTs) (Vander Heiden and Thompson, 1999; Zamzami and Kroemer, 2001). We found that CsA inhibited TNFinduced cell death in all three L929 lines to a similar degree (35\%-39\% inhibition) (Fig. 3A). The inhibitory effect of CsA on TNF-induced cell death was also observed in MCF-7.3.28 cells that express Meta $\triangle T M / C$ or Bcl- $X_{L}$ (Fig. $3 B$ ). This data confirms that TNF-induced cell death depends on PT, and suggests that metaxin deficiency or $\mathrm{Bcl}-\mathrm{X}_{\mathrm{L}}$ overexpression did not affect CsA's regulation of the PT pore.

\section{Metaxin-deficiency and $\mathrm{Bcl}-\mathrm{X}_{\mathrm{L}}$-overexpression did not alter mitochondrial membrane potential $\left(\Delta \Psi_{m}\right)$ but reduced staining of membrane-potential probes in the presence of FCCP}

The loss of inner mitochondrial membrane potential resulted from increases in PT are believed to be essential in many cell death processes (Pastorino et al., 1996; Kroemer and Reed, 2000). The proton gradient is the major source of mitochondrial membrane potential in cells undergoing oxidative phosphorylation. Carbonyl cyanide $\mathrm{p}$-(trifluormethoxy)phenylhydrazone (FCCP) is an uncoupler of oxidative phosphorylation in mitochondria, dissipating the proton gradient generated by the electron transport chain (Gardner and Collins, 2000). To examine the effect of metaxin deficiency and $\mathrm{Bcl}-\mathrm{X}_{\mathrm{L}}$ overexpression on mitochondrial $\Delta \psi_{\mathrm{m}}$, we used the mitochondrial membrane potential probes Rh123 and 3'3'-dihexyloxacarbocyanine iodode $\left(\mathrm{DiOC}_{(6)}\right)$ to compare $\Delta \psi_{\mathrm{m}}$ in the different L929 lines. Accumulation of Rh123 in TNF-sensitive and TNF-resistant L929 cells was similar (controls, Fig. 4A). The same result was obtained when $\mathrm{DiOC}_{(6)}$ was used (data not shown). As expected, pretreatment of parental, Meta ${ }^{\text {mut }}$, and $B c l-X_{L}$ cells with FCCP resulted in a decreased uptake of Rh123 (Fig. 4A) or $\mathrm{DiOC}_{(6)}$ (data not shown). Interestingly, the levels of these dyes in the mitochondria in the presence of FCCP were significantly different. Metaxin-deficient and $\mathrm{Bcl}-\mathrm{X}_{\mathrm{L}}$-overexpressing cells had less Rh123 (Fig. 4A) or $\mathrm{DiOC}_{(6)}$ (data not shown) accumulation when compared with parental cells $(20 \%$ and $22 \%$ of control vs. $40 \%$ of control). Pretreatment of cells with TNF did not affect Rh123 accumulation after FCCP addition (data not shown).

To further examine this phenomenon, we incubated cells with Rh123 and then treated cells with FCCP. Rh123 intensity was quickly reduced in all three lines in the first four hours, and thereafter maintained (Fig. 4B). Parental cells retained a higher level of Rh123 compared to Meta ${ }^{\text {mut }}$ - and $\mathrm{Bcl}-\mathrm{X}_{\mathrm{L}}$ transfected lines, which is consistent with the results obtained in Fig. 4A. As for the results obtained with pretreatment of FCCP, TNF-treatment did not influence Rh123 levels (data not shown).

Rh123- or DiOC $(6)$-staining in the presence of FCCP could be achieved by nonspecific binding of the dye to membranes and/or uptake of the dyes by means other than the proton gradient. The difference observed between parental and metaxin-deficient or $\mathrm{Bcl}-\mathrm{X}_{\mathrm{L}}$-overexpressing cells in their accumulation of $\mathrm{Rh} 123$ or $\mathrm{DiOC}_{(6)}$ in the presence of FCCP is not likely to be caused by nonspecific binding of dyes, because the size and number of mitochondria per cell were comparable in all three lines (Fig. 4C). TNF stimulation did not have a significant effect on mitochondrial quantity or size. Since the level of $\mathrm{Rh} 123$ or $\mathrm{DiOC}_{(6)}$ accumulation reflects the balance between the dye influx and efflux, metaxin deficiency or Bcl- $\mathrm{X}_{\mathrm{L}}$-overexpression in $\mathrm{L} 929$ cells could either decrease the proton gradient-independent influx of the dye, or increase the dye efflux.

\section{Metaxin-deficient, Meta $\Delta \mathrm{TM} / \mathrm{C}$-expressing, and $\mathrm{Bcl}-\mathrm{X}_{\mathrm{L}}$ - overexpressing cells show a quicker release of $\mathrm{Rh} 123$ in comparison with parental cells}

To determine whether there is a difference among the

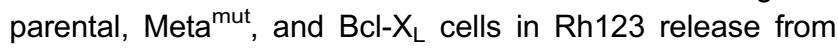
the mitochondria, we loaded the cells with Rh123 and then replaced the medium with an Rh123-free medium. The cells were left untreated, or were treated with TNF; Rh123 fluorescence was measured at different time points after the 
A
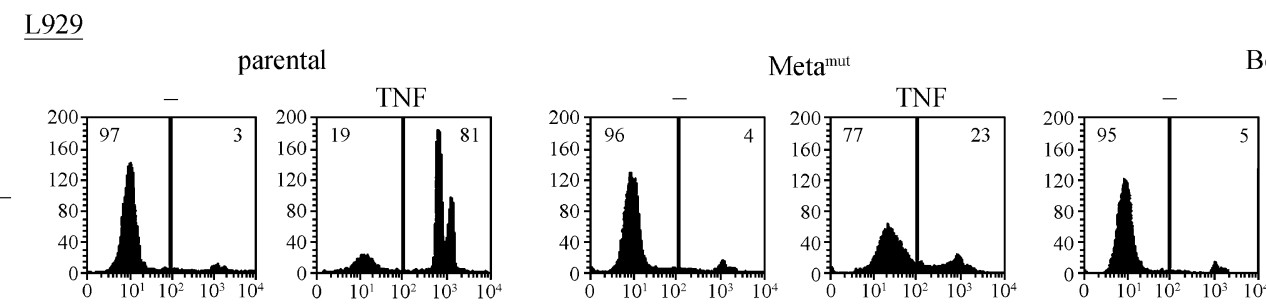

$\mathrm{Bcl}-\mathrm{X}_{\mathrm{L}}$
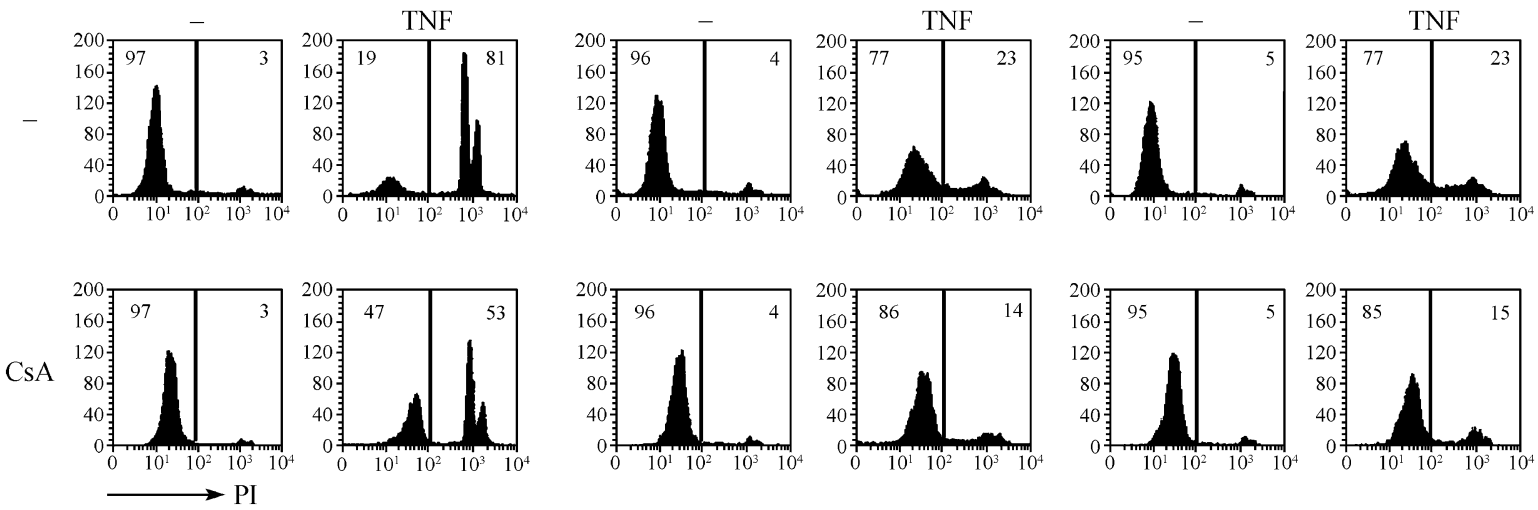

B

MCF-7.3.28
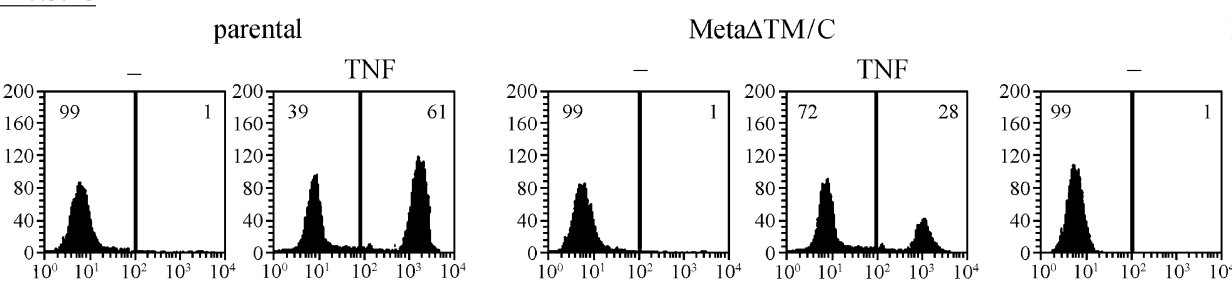

$\mathrm{Bcl}-\mathrm{X}_{\mathrm{L}}$
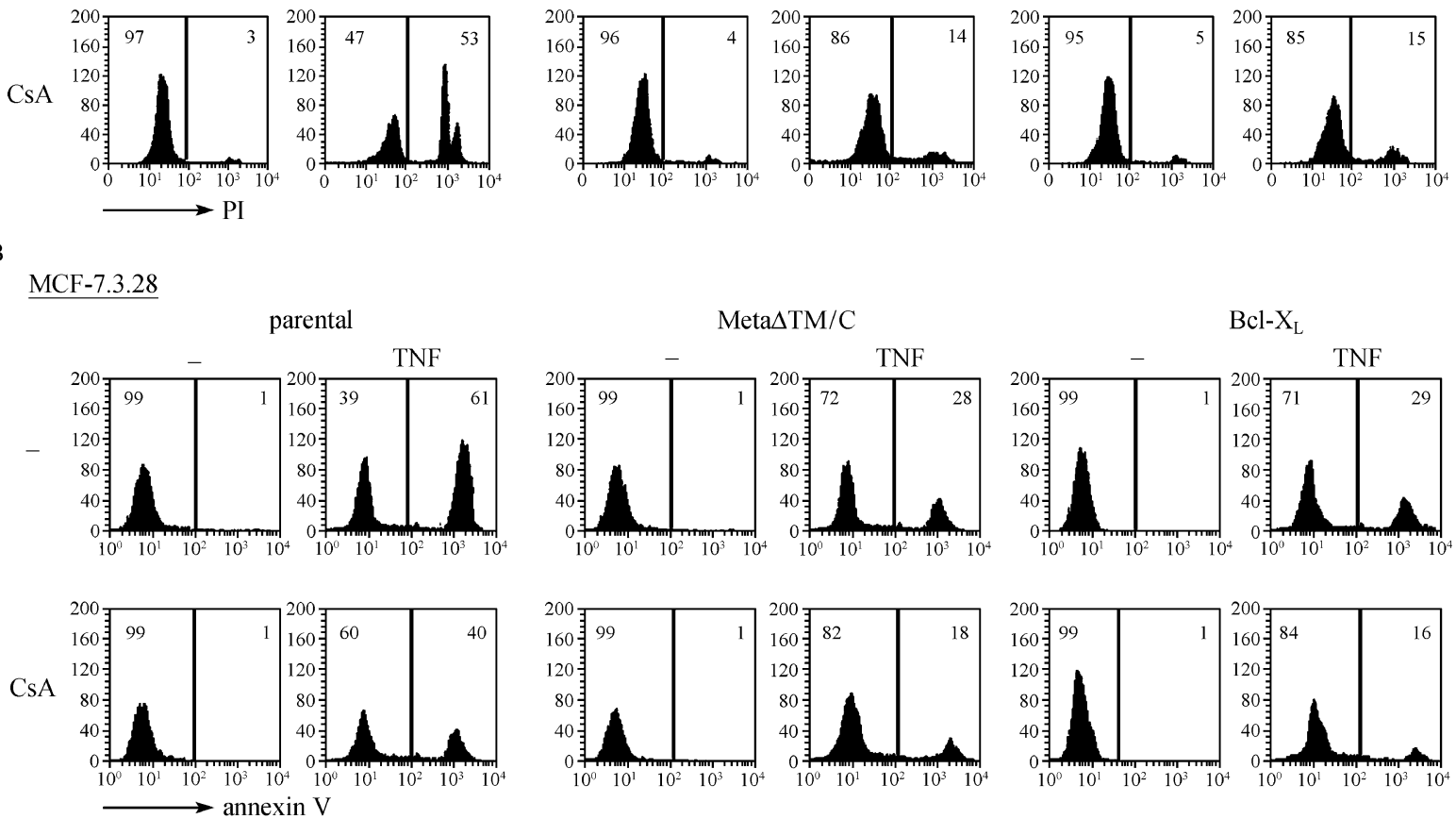

Figure 3. Cyclosporin A (CsA) equally affects TNF-induced cell death in wild-type, metaxin-deficient, Meta $\Delta$ TM/Coverexpressing, and $\mathrm{Bcl}-\mathrm{X}_{\mathrm{L}}$-overexpressing cells. (A) Parental, Meta ${ }^{\text {mut }}$, and $\mathrm{Bcl}-\mathrm{X}_{\mathrm{L}}$-overexpressed $\mathrm{L} 929$ cells were treated with or without TNF in the presence or absence of $5 \mu \mathrm{M}$ CsA. PI staining was analyzed $24 \mathrm{~h}$ after TNF stimulation. Cells were gated into two regions according to their PI levels, and their percentages are shown inside each rectangular region. (B) MCF-7.3.28 cells, transfected with empty vector, Meta $\Delta \mathrm{TM} / \mathrm{C}$, or Bcl- $\mathrm{X}_{\mathrm{L}}$, were treated with or without TNF in the presence or absence of $5 \mu \mathrm{M}$ CsA. Annexin $\mathrm{V}$ staining was analyzed $24 \mathrm{~h}$ after TNF stimulation. Cells were gated into two regions according to their annexin staining levels, and their percentages are shown inside each rectangular region. CsA reduced death to a similar degree in wild-type, metaxindeficient, Meta $\Delta \mathrm{TM} / \mathrm{C}$-expressing, and $\mathrm{Bcl}-\mathrm{X}_{\mathrm{L}}$-overexpressing cells.

cells had been placed in the Rh123-free medium. As shown in Fig. 5A, Rh123-staining was gradually reduced in all three lines, while the parental L929 cells had a significantly slower reduction of Rh123 fluorescence $\left(T_{1 / 2}\right.$ is about $3 h$ ) than the other two lines $\left(T_{1 / 2}=2 / 3 \mathrm{~h}\right)$. TNF-treatment for 2-6 h did not influence the rate of $\mathrm{Rh} 123$ release in any of the three lines (data not shown). The PT inhibitor CsA (Liu and Colombini, 1992; Pastorino et al., 1996) inhibited the Rh123 reduction in all three cell lines (right panel of Fig. 5A), confirming that Rh123 was loaded into the mitochondria and released after Rh123 was removed from the cell culture media. This also suggests that PT is involved in the release of Rh123. The kinetics of Rh123 release from the mitochondria (Fig. 5A) and
FCCP-induced reduction of Rh123 (Fig. 4B) were very similar, suggesting that the difference in the rate of $\mathrm{Rh} 123$ release was, at least in part, responsible for the difference in the proton gradient-independent Rh123 accumulation observed in the three cell lines (Fig. 4A).

To determine whether the quicker release of preloaded Rh123 is correlated with TNF resistance in different cell lines, we examined parental, metaxin-transfected, or Meta $\Delta T M / C$ transfected L929 cells, and parental, Meta $\Delta T M / C$-transfected, or Bcl- $\mathrm{X}_{\mathrm{L}}$-transfected MCF-7.3.25 cells. As shown in Fig. 5B and $5 \mathrm{C}$, the cells transfected with Meta $\Delta \mathrm{TM} / \mathrm{C}$ or Bcl- $\mathrm{X}_{\mathrm{L}}$, which are resistant to TNF-induced killing (Fig. 2), released Rh123 more rapidly than TNF-sensitive cells. Therefore, there is a 
A

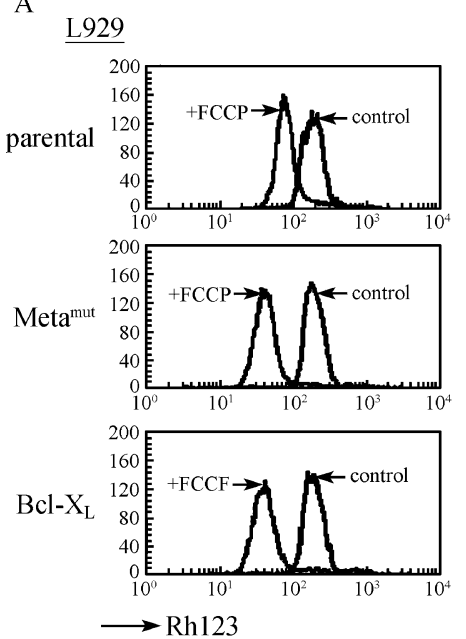

B

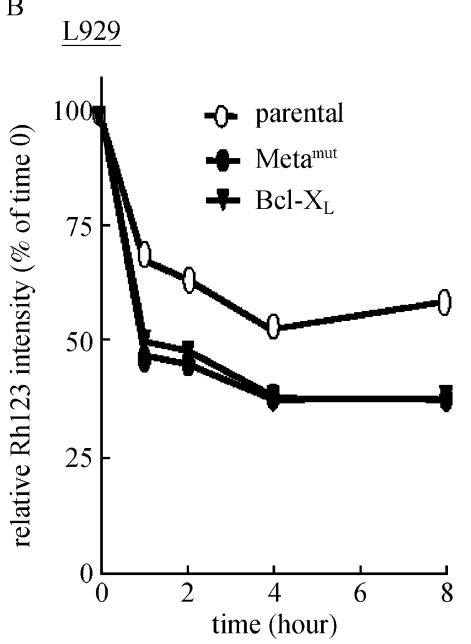

$\mathrm{C}$
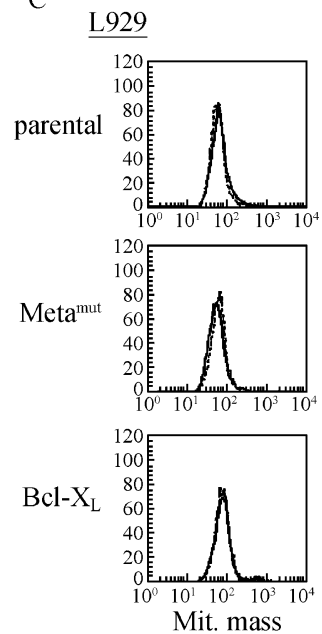
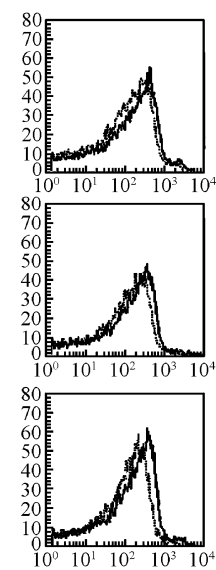

Mit. size

Figure 4. Metaxin-deficient and $\mathrm{Bcl}-\mathrm{X}_{\mathrm{L}}$-overexpressing $\mathrm{L} 929$ cells have comparable $\Delta \boldsymbol{\Psi}_{\mathrm{m}}$ values with that of parental cells, but have decreased Rh123 staining in the presence of FCCP. (A) Parental, Meta ${ }^{\text {mut }}$, and Bcl- $\mathrm{X}_{\mathrm{L}}$ - overexpressing L929 cells were pretreated with or without FCCP for $30 \mathrm{~min}$, and Rh123 accumulation levels in mitochondria were measured. All three lines had similar levels of Rh123 accumulation (controls), indicating comparable $\Delta \psi_{\mathrm{m}}$, while Meta ${ }^{\text {mut }}$ and $\mathrm{Bcl}-\mathrm{X}_{\mathrm{L}}$ cells had less Rh123 staining in the presence of FCCP (+ FCCP). (B) Parental, Meta ${ }^{\text {mut }}$, and Bcl- $X_{L}$ cells were treated with Rh123 for 30 min and FCCP was then added. Rh123 intensity was determined at different times after addition of FCCP using flow cytometry. The relative Rh123 intensity was calculated by using the amount of Rh123 staining obtained from the cells without FCCP treatment (time 0 ) as $100 \%$. (C) Parental, Meta ${ }^{\text {mut }}$, and Bcl-X $X_{L}$ L929 cells were treated with TNF for 6, 12 or $24 \mathrm{~h}$ and the size and number of their mitochondria were analyzed. Mitochondria quantity was assessed by Mitotracker-Green ${ }^{\mathrm{TM}}$ staining, and mitochondria size was measured by forward scatter on isolated mitochondria. Dotted curves represent results from cells without TNF treatment. Similar results were obtained for all time points, and data obtained at a time-point of $6 \mathrm{~h}$ is shown.

good correlation between TNF resistance and the rate of Rh123 release.

Rh123 is a cell-permanent cationic and fluorescent dye that is accumulated in the matrix of active mitochondria as a result of the mitochondrial membrane potential. The levels of Rh123 in mitochondria are determined by the balance between the $\Delta \psi_{\mathrm{m}}$-dependent influx of the dye and the efflux of Rh123. Rh123 was normally not retained in cells when they were removed from the media, which is due to a cessation of its influx. It is believed that the release of Rh123 is not regulated because the dye is freely membrane-permeable. However, Rh123 release from the mitochondria may not be as free as was previously thought. The PT inhibitor CsA can inhibit the release of preloaded Rh123 in all of the cell lines tested (Fig. 5A-C). The reported observation that many carcinoma cells retain Rh123 for longer periods of time also suggests that the release of molecules like Rh123 can be controlled (Bernal et al., 1982; Nadakavukaren et al., 1985). Since the difference in the rate of Rh123 release among TNFresistant and TNF-sensitive cells was observed in the resting stage, and since TNF treatment had no effect on the speed of $\mathrm{Rh} 123$ release, the difference in $\mathrm{Rh} 123$ release cannot be a result of an altered TNF response in TNF-resistant cells, but instead, it must be a direct consequence of $\mathrm{Bcl}-\mathrm{X}_{\mathrm{L}}$-overexpression or metaxin deficiency. Because both metaxin and $B c l-X_{L}$ are located on the outer mitochondrial membrane, we sought to determine whether the increased Rh123 release in Metamut and $\mathrm{Bcl}-\mathrm{X}_{\mathrm{L}}$-transfected lines was related to mitochondrial membrane structure by disrupting the outer mitochondrial membrane with digitonin (Dig) in vitro. We loaded mitochondria with Rh123 and then placed the cells in an Rh123-free medium. Mitochondria were isolated from different cells at different times after being changed to the Rh123-free medium. Rh123 intensity was measured using half of the mitochondria samples. The remaining mitochondrial samples were treated with digitonin to permeabilize the outer mitochondrial membrane before measuring Rh123 intensity. Mitochondria isolated from the parental line exhibited greater Rh123 retention than those from Metamut cells (Fig. 5D), which is consistent with the results obtained using whole cells (Fig. 5A). Permeabilizing the outer mitochondrial membrane produced no changes in the Rh123 staining of mitochondria isolated from Metamut cells. Similar results were obtained using $\mathrm{Bcl}-\mathrm{X}_{\mathrm{L}}$ cells (data not shown). By contrast, digitonin treatment reduced $\mathrm{Rh} 123$ retention in mitochondria isolated from parental cells (Fig. 5D). When the PT inhibitor CsA was included, digitonin treatment led to only a slight decrease in Rh123 staining in mitochondria isolated from parental cells (Fig. 4D), suggesting that CsA inhibits Rh123 release at a very early step. It appears that both metaxin-deficient and 
A

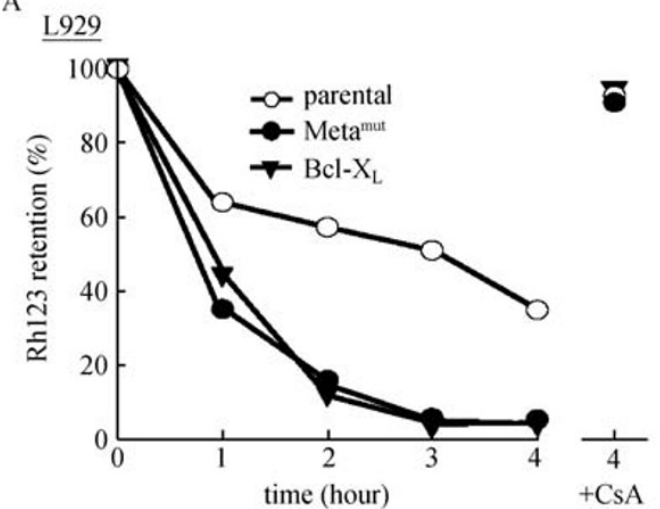

$\mathrm{C}$

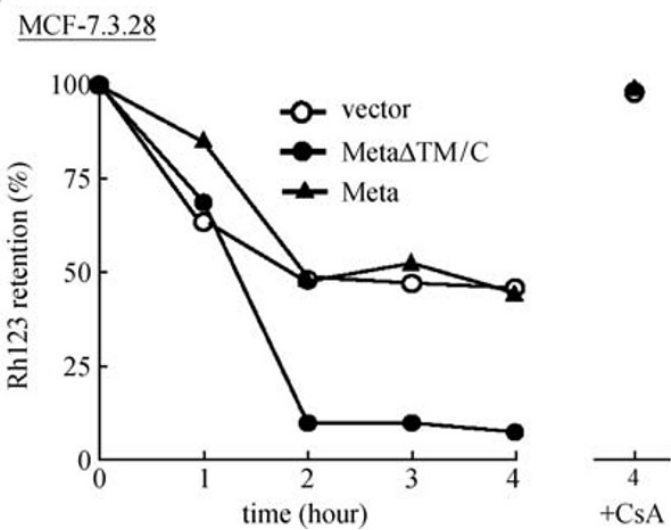

B

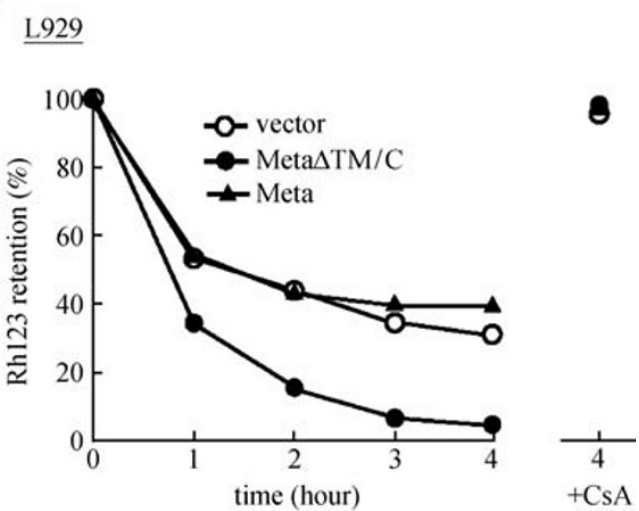

D

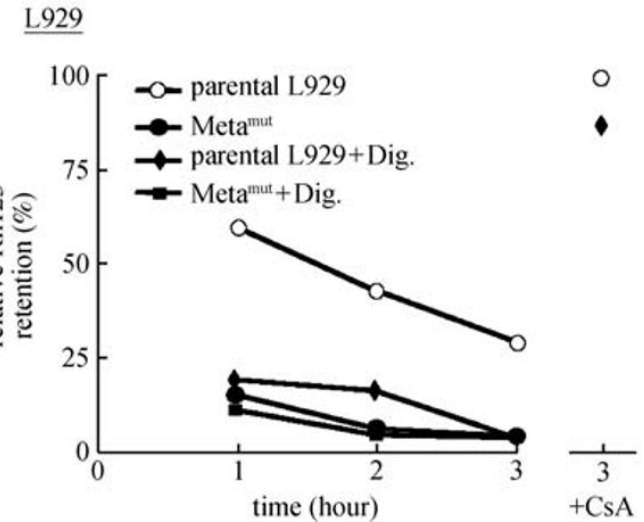

Figure 5. Metaxin-deficient, and Meta $\Delta T M / C$ - or $B c l-X_{L}$-overexpressing cells have increased release rates of preloaded $\mathrm{Rh}_{123}$, which is most likely caused by the effect of metaxin and $\mathrm{Bcl}-\mathrm{X}_{\mathrm{L}}$ on the outer mitochondrial membrane. (A) Rh123 retention was analyzed in parental, Metamut and Bcl- $X_{L}$ cell lines. Cells were preloaded with Rh123 for 30 min before the cells were washed, incubated with fresh Rh123-free media for the indicated times and Rh123 levels retained in the cells were measured by flow cytometry. Results from cells incubated with fresh Rh123-free medium plus $5 \mu \mathrm{M}$ cyclosporin A (CsA) after washing are also included. Mean Rh123 levels from cells in Rh123-containing media (time 0) were taken as $100 \%$ and the basal

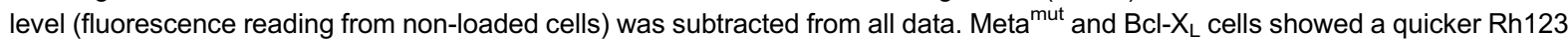
release than parental cells. (B) Rh123 retention was analyzed in L929 cells transfected with empty vector, Meta $\Delta$ TM/C, or metaxin as described in (A). (C) Rh123 retention was analyzed in MCF-7.3.28 cells transfected with empty vector, Meta $\Delta T M / C$, or metaxin as described in (A). (D) Parental and Metamut L929 cells were preloaded with Rh123. The cells were washed and placed into an Rh123free medium. Cells were harvested and mitochondria were isolated. Half of the mitochondrial samples were treated with $0.12 \%$ digitonin (Dig) for $2 \mathrm{~min}$ and the other half were left untreated. Rh123 intensity was measured using flow cytometry. Five $\mu \mathrm{M}$ CsA was added to the indicated samples. The mean value of the sample processed in the presence of CsA, and without digitonin treatment, was used as $100 \%$ for purposes of calculating relative Rh123 intensity. Permeabilizing the outer mitochondrial membrane reduced Rh123 retention in parental cells.

Bcl- $\mathrm{X}_{\mathrm{L}}$-overexpressing cell lines harbor mitochondrial membrane alterations, leading to their increased permeability to Rh123.

\section{The regulated opening of PT pore does not change the speed of $\mathrm{Rh} 123$ release.}

In many models of death induction, the reduction of the $\Delta \psi_{\mathrm{m}}$ is observed shortly before other features of cell death (Kroemer and Reed, 2000). It is believed that the reduction of $\Delta \Psi_{\mathrm{m}}$ is a consequence of the PT pore opening. The inhibitory effect of
CsA on Rh123 release suggests an involvement of the PT pore in the release of preloaded Rh123 from the mitochondria. It is important to note that the efficiency of the CsA blockage of Rh123 release in parental, metaxin-deficient, and $\mathrm{Bcl}-\mathrm{X}_{\mathrm{L}}$-overexpressing cells is the same (Fig. 4), suggesting that the site targeted by CsA in the release of Rh123 is different from the site influenced by metaxin deficiency or Bcl$X_{L}$ overexpression. To further examine whether the different rates of $\mathrm{Rh} 123$ release in metaxin-deficient and $\mathrm{Bcl}-\mathrm{X}_{\mathrm{L}}$ overexpressing cells is related to the PT pore opening during cell death, we used lonidamine (LND), an antineoplastic drug 
that directly opens the PT pore to induce cell death (Ravagnan et al., 1999). Cells began to die about $8 \mathrm{~h}$ after LND treatment, with parental cells demonstrating a higher mortality rate $(36 \%)$ compared to Metamut $(3 \%)$ or $B c l-X_{L}$ cells (6\%) (Fig. 6A). A reduction in $\Delta \psi_{m}$ was observed before cells began to die, and the resistant lines had a smaller $\Delta \psi_{\mathrm{m}}$ reduction compared to the parental line (Fig. 6B). We preloaded mitochondria with Rh123 and then measured the speed of Rh123 release after LND treatment. As in the absence of LND treatment (Fig. 5A), Rh123 release was still more rapid in resistant lines in the presence of LND (Fig. 6C), suggesting that PT opening by LND does not impact the rate of $\mathrm{Rh} 123$ release.

\section{DISCUSSION}

It is known that mitochondria play an important role in TNFinduced death in L929 and MCF-7 cells (Golstein et al., 1991; Fiers et al., 1999). Our previous work demonstrated that the mitochondrial outer membrane protein metaxin is required for TNF-induced cell death (Wang et al., 2001). In this study, we analyzed the death resistance in metaxin-deficient cells in parallel with $\mathrm{Bcl}-\mathrm{X}_{\mathrm{L}}$-overexpressing cells, and showed that a common feature of metaxin deficiency and $\mathrm{Bcl}-\mathrm{X}_{\mathrm{L}}$ overexpression is the more rapid release of $\mathrm{Rh} 123$ from the mitochondria when compared to wild-type parental cells. The correlation between quicker Rh123 release and death resistance suggests that mitochondrial structures that control the Rh123 release may influence TNF-induced cell death. Our data indicate that the quicker release of preloaded Rh123 mediated by metaxin deficiency and $\mathrm{Bcl}-\mathrm{X}_{\mathrm{L}}$-overexpression is not related to the regulated closing and opening of the PT pore, and is likely due to an unknown structural alteration of the mitochondrial outer membrane.
The inhibitory effect of CsA on Rh123 release may be exerted at the inner membrane part of PT pore because the mitochondrial target of CsA, cyclophilin, is located inside the inner membrane (Kunz and Hall, 1993). This is consistent with the data showing that the efficiency of CsA's blockage of Rh123 release in parental, metaxin-deficient and $\mathrm{Bcl}-\mathrm{X}_{\mathrm{L}}$ overexpressing cells is the same (Fig. $5 \mathrm{~A}$ ) because metaxin and $\mathrm{Bcl}-\mathrm{X}_{\mathrm{L}}$ are located on the outer membrane of the mitochondria. Metaxin and $\mathrm{Bcl}-\mathrm{X}_{\mathrm{L}}$ may interact with the outer membrane components of the PT pore, such as VDAC, and thereby influence the PT pore. However, this cannot explain why CsA inhibits Rh123 release and blocks cell death, while metaxin deficiency or $\mathrm{Bcl}-\mathrm{X}_{\mathrm{L}}$-overexpression increases Rh123 release and also inhibits cell death. One of the possibilities is that the rate of $\mathrm{Rh} 123$ release is not related with cell death. However, the correlation is observed not only in L929, but also MCF-7 cells, suggesting that there is an intrinsic linkage between the mitochondrial machineries in control of cell death and $\mathrm{Rh} 123$ release.

The PT pore is believed to reside in the across sites of contact between the inner and outer membranes. However, the association of pore components in the inner membrane (such as ANT) and the outer membrane (VDAC) could be dynamic. It is believed that PT pore components in the inner mitochondrial membrane control the state of the PT, and the outer mitochondrial membrane is not believed to be a barrier to small molecules because VDAC is a large channel that, in its opening configuration, is permeable to uncharged molecules up to $\sim 5000 \mathrm{kDa}$. However, a study showed that outer membrane permeability to metabolic compounds was reduced in the cell death process (Vander Heiden et al., 2000). Since metaxin and $\mathrm{Bcl}-\mathrm{X}_{\mathrm{L}}$ are outer mitochondrial membrane proteins, the quicker release of Rh123 mediated by metaxin deficiency and $\mathrm{Bcl}-\mathrm{X}_{\mathrm{L}}$-overexpression is independent from the
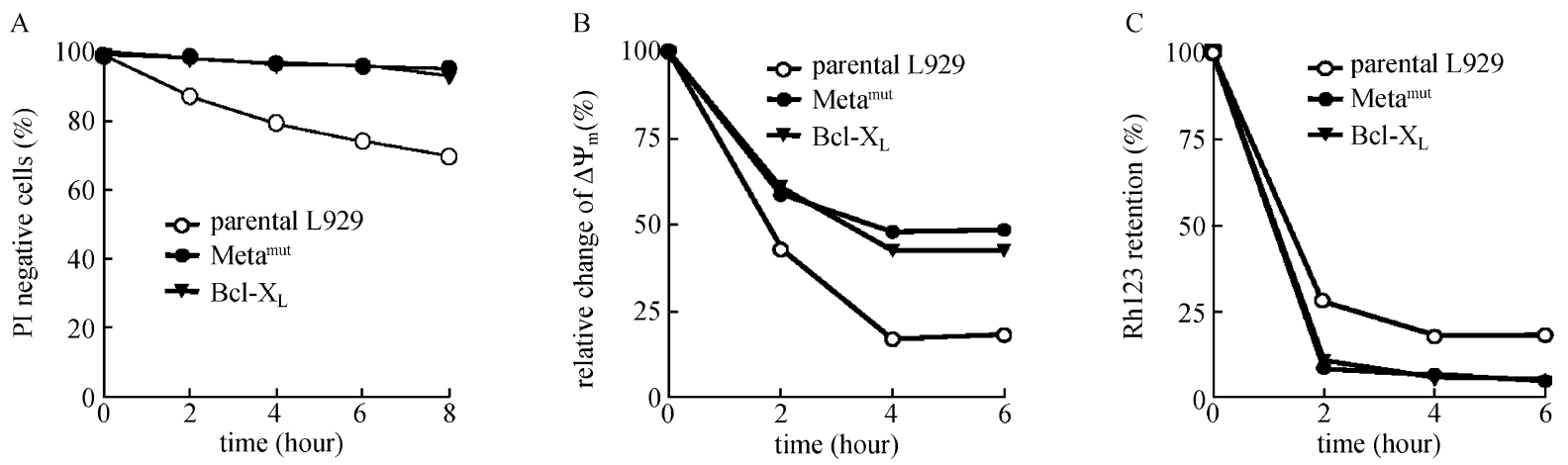

Figure 6. Increased mitochondrial membrane permeability to molecules like Rh123 may help to maintain $\Delta \Psi_{\mathrm{m}}$. (A) Parental, Meta ${ }^{\text {mut }}$, and Bcl- $X_{L}$ L929 cells were treated with $800 \mu \mathrm{M}$ lonidamine (LND) for different periods of time. Cell viability was measured by PI staining. (B) Parental, Metamut, and Bcl- $X_{L}$ L929 cells were treated with LND, and $\Delta \Psi_{m}$ was measured at different time points. Relative changes of $\Delta \psi_{\mathrm{m}}$ were calculated by taking time 0 as $100 \%$ and subtracting plasma potential from all data. Parental cells had a greater $\Delta \psi_{m}$ reduction than Meta ${ }^{\text {mut }}$ and Bcl- $\mathrm{X}_{\mathrm{L}}$ cells. (C) Parental, Meta ${ }^{\mathrm{mut}}$, and Bcl- $\mathrm{X}_{\mathrm{L}}$-overexpressing cells were cultured in the presence of LND, and Rh123 retention was measured. The release of Rh123 was slower in parental cells. 
regulated opening and closing of the PT pore, and therefore, it is possible that the permeability of the outer mitochondrial membrane contributes to the phenomenon observed in this study. One can assume that TNF-induced dysfunction of the mitochondria, such as in massive ROS production in the matrix, may be associated with mitochondrial depolarization (Schulze-Osthoff et al., 1992), which leads to a movement of molecules or ions from the matrix into the intermembrane space. If this occurs more quickly than the rate of diffusion through the outer membrane, osmolarity will be increased in the intermembrane space and pressure will build up on the outer membrane, leading to membrane damage. Either $\mathrm{Bcl}-\mathrm{X}_{\mathrm{L}}$-overexpression or metaxin deficiency alone may increase outer membrane permeability, creating a bypass that alleviates the pressure imposed on the outer membrane. CsA may attenuate PT pore opening to prevent mitochondrial depolarization, thus inhibiting the efflux from the matrix to the intermembrane space. This model explains our observation that both blocking Rh123 release at an inner membrane site by CsA and increasing Rh123 release by alteration of outer membrane by metaxin deficiency or Bcl- $\mathrm{X}_{\mathrm{L}}$ overexpression inhibit cell death. However, we do not have sufficient evidence to draw a conclusion at this moment. Nevertheless, $\mathrm{Bcl}-\mathrm{X}_{\mathrm{L}}$ overexpression and metaxin deficiency appear to alter outer mitochondrial membrane permeability and therefore influence cell death.

The importance of the outer mitochondrial membrane in cell death has been well documented (Vander Heiden and Thompson, 1999). The release of apoptogenic factors originally located in the mitochondrial intermembrane space through the outer membrane is a common trigger for many types of cell death. However, the mechanism by which the outer membrane controls cell death is still controversial. Bax, a pro-apoptotic member of the $\mathrm{Bcl}-2$ family, has been shown to interact directly with VDAC and accelerate the opening of VDAC in artificial VDAC liposomes, whereas $B C l-X_{L}$ closes this porin when added to reconstituted liposomes (Shimizu et al., 1999). Bax-mediated Cyt c release in isolated yeast mitochondria is dependent on VDAC (Shimizu et al., 1999), and can be prevented by Bcl- $X_{L}$ (Shimizu et al., 1999). However, Bax-induced yeast killing is not VDAC-dependent (Gross et al., 2000; Harris et al., 2000). Rather, a recent report suggests that $\mathrm{Bcl}-\mathrm{X}_{\mathrm{L}}$-overexpression actually prevents VDAC from assuming its closed configuration (Vander Heiden et al., 2000). Therefore, whether and how Bcl-2 family members exert their effects on apoptosis through interaction with VDAC remains unclear.

It should be noted that Rh123 is a cation. An in vitro study shows that closure of VDAC does not reduce cation flux (Liu and Colombini, 1992), suggesting that there may be an involvement of other kinds of porin(s). It is known that Bcl- $X_{L}$ can form channels by itself (Minn et al., 1997), thus increase the permeability of the outer mitochondrial membrane. The involvement of the general import pore (GIP) in metabolic transport across the outer mitochondrial membrane was suggested recently (Kmita and Budzinska, 2000; Antos et al., 2001). It is possible that metaxin influences the outer mitochondrial membrane permeability via GIP. Whether an increase in outer membrane permeability generally favors cell survival in other cell systems is a subject for further investigation.

In summary, we compared Bcl- $\mathrm{X}_{\mathrm{L}}$ overexpression- and metaxin deficiency-mediated resistance to TNF-induced cell killing in both L929 and MCF-7 cells. A common feature found in both cell lines is an increased rate of Rh123 release from the mitochondria. Such a change is most likely caused by an alteration of the outer mitochondrial membrane and is linked to the acquired resistance to TNF-induced cell killing. We suggest that the increase in outer membrane permeability reduces the pressure imposed on the outer mitochondrial membrane from the intermembrane space, and helps to prevent the loss of outer mitochondrial membrane integrity and subsequent cell death.

\section{MATERIALS AND METHODS}

\section{Cells and cell culture}

L929 murine fibrosarcoma cells from ATCC were cultured in RPMI1640 medium, supplemented with $10 \%$ fetal bovine serum, 100 units of penicillin $\mathrm{G}$ sodium $/ 100 \mu \mathrm{g} / \mathrm{mL}$ streptomycin sulfate, $292 \mu \mathrm{g} / \mathrm{mL} \mathrm{L}$ glutamine, $10 \mathrm{mM}$ HEPES, $100 \mu \mathrm{M}$ non-essential amino acids mixture, and $1 \mathrm{mM}$ sodium pyruvate (Gibco BRL, NY). TNF sensitivity was tested, revealing $a<1 \times 10^{-6}$ spontaneous survival rate at a dose of $100 \mathrm{ng} / \mathrm{mL}$ TNF for $48 \mathrm{~h}$. No nuclear condensation, DNA fragmentation, Cyt c release, caspase-3 activation, or PARP cleavage was detected during TNF treatment. Stable cell lines derived from L929 cells were established either by retroviral infection or plasmid transfection with the GenePorter ${ }^{\mathrm{TM}}$ transfection reagent (GTS Inc., San Diego, CA). Selection of transfected clones was performed by adding $1 \mathrm{mg} / \mathrm{mL}$ G-418 or $10 \mu \mathrm{g} / \mathrm{mL}$ blasticidin $\mathrm{S}$ (Invitrogen, San Diego, CA) to the culture medium.

Induction of cell death and cell survival assay using propidium iodide or annexin staining

Mouse recombinant TNF was used at a concentration of $100 \mathrm{ng} / \mathrm{mL}$ unless otherwise indicated. Antimycin A (Sigma, St. Louis, MO) was dissolved in ethanol to a final concentration of $10 \mu \mathrm{M}$. Plasma membrane integrity was determined according to the exclusion of propidium iodide (PI). Cells were trypsinized and collected by centrifugation. Cells were then washed once with PBS and resuspended in PBS containing $1 \mu \mathrm{g} / \mathrm{mL}$ propidium iodide (Sigma) and quantified by flow cytometry on a FACScan flow cytometer (Becton Dickinson, AZ) with CellQuest ${ }^{\mathrm{TM}}$ acquisition/analysis software. The annexin V-FITC kit (Roche Molecular Biochemicals, Idianapolis, IN) was used to measure PS flipping according to the manufacturer's protocol.

\section{Measurement of ATP levels}

Intracellular ATP levels were measured using the ATP Bioluminescence assay kit HS II (Roche Molecular Biochemicals), following the 
manufacturer's protocol. Luciferase reagent $(50 \mu \mathrm{L})$ was automatically injected into $50 \mu \mathrm{L}$ of each cell lysate and the luminescence was analyzed after a $1.6 \mathrm{~s}$ delay and $5 \mathrm{~s}$ integration with a MicroLumatPlus microplate luminometer (EG\&G Berthold, Gaithersburg, MD).

\section{Mitochondrial isolation and analysis}

Cells, prestained with rhodamine, were lysed by 20 strokes in a Dounce homogenizer (pestle B) and the mitochondrial fraction was obtained by differential centrifugation as described (Vander Heiden et al., 2000). The mitochondrial pellets were resuspended in assay buffer ( $220 \mathrm{mM}$ mannitol, $70 \mathrm{mM}$ sucrose, $2 \mathrm{mM}$ HEPES, $0.2 \mathrm{mM}$ EGTA, $5 \mathrm{mM}$ succinate, $0.5 \% \mathrm{BSA}$, and $5 \mu \mathrm{M}$ rotenone) and mitochondrial size was determined by flow cytometry. Permeabilization of the outer membrane of the mitochondria was achieved by treating isolated mitochondria with digitonin $(0.12 \%)$ (Calbiochem La Jolla, CA) for $5 \mathrm{~min}$ as described (Schnaitman and Greenawalt, 1968; Vander Heiden et al., 2000).

\section{Mitochondrial staining}

For the measurement of mitochondrial membrane potential, cells

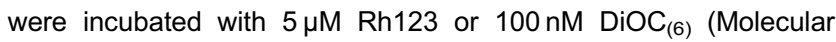
Probes, OR) for $30 \mathrm{~min}$ before collection and analysis by flow cytometry. Plasma membrane potential was determined by staining the cells with $\mathrm{Rh} 123$ in either complete medium with $140 \mathrm{mM} \mathrm{NaCl}$, or $140 \mathrm{mM} \mathrm{KCl}$, the later abolishes plasma membrane potential and a subtraction yields plasma membrane potential. For measuring the number of mitochondria, $200 \mathrm{nM}$ MitoTracker Green FM (Molecular Probes) was added to the cells $1 \mathrm{~h}$ before analysis by flow cytometry. For the measurement of rhodamine retention, cells were pretreated with $5 \mu \mathrm{M}$ Rh123 for $30 \mathrm{~min}$. Then, excess rhodamine was removed by washing, and the cells were incubated at $37^{\circ} \mathrm{C}$ for the indicated lengths of time before cellular levels of Rh123 were measured by flow cytometry.

\section{Other measurements}

Mitochondrial ROS was measured using dihydrorhodamine 123 (DHR123) or hydroethidine (HE) as described (Goossens et al., 1995). Proliferation was measured using ${ }^{3} \mathrm{H}$-thymidine incorporation. Cyt $c$ redistribution was determined by the fractionation of the mitochondria and the cytosol, and was analyzed by Western blotting as described (Yang et al., 1997). Caspase activity was measured using a colorimetric caspase assay kit (Calbiochem, San Diego, CA). Nuclear condensation and fragmentation were determined by staining the cells with HOE 33258 (Sigma).

\section{ACKNOWLEDGEMENTS}

This work was supported by NIH grants Al41637 and AI68896.

\section{ABBREVIATIONS}

ANTs, adenine nucleotide translocases; CsA, cyclosporin A; Cyt c, cytochrome c; DD, death domain; Dig, digitonin; $\mathrm{DiOC}_{(6)}, 3^{\prime} 3$ 'dihexyloxacarbocyanine iodode; DHR123, dihydrorhodamine 123; FACS, flow cytometric; FCCP, carbonyl cyanide p-(trifluormethoxy) phenylhydrazone; GC, glucocerebrosidase; GIP, general import pore; $\mathrm{HE}$, hydroethidine; LND, lonidamine; PI, propidium iodide; PT, permeability transition; Rh123, rhodamine 123; RIP, receptor interacting protein; TNF, tumor necrosis factor-a; TNF-RI, TNF receptor I; VDAC, voltage-dependent anion channel

\section{REFERENCES}

Adams, J.M., and Cory, S. (1998). The Bcl-2 protein family: arbiters of cell survival. Science 281, 1322-1326.

Antos, N., Budzinska, M., and Kmita, H. (2001). An interplay between the TOM complex and porin isoforms in the yeast Saccharomy cescerevisiae mitochondria. FEBS Lett 500, 12-16.

Armstrong, L.C., Komiya, T., Bergman, B.E., Mihara, K., and Bornstein, P. (1997). Metaxin is a component of a preprotein import complexin the outer membrane of the mammalian mitochondrion. J Biol Chem 272, 6510-6518.

Bernal, S.D., Lampidis, T.J., Summerhayes, I.C., and Chen, L.B. (1982). Rhodamine-123 selectively reduces clonal growth of carcinoma cells in vitro. Science 218, 1117-1119.

Beutler, B., and Cerami, A. (1986). Cachectin and tumour necrosis factor as two sides of the same biological coin. Nature 320 , 584-588.

Beutler, B., and Cerami, A. (1988). Tumor necrosis, cachexia, shock, and inflammation: A common mediator. Ann Rev Biochem 57, 505-518.

Beyaert, R. and Fiers, W. (1994). Molecular mechanisms of tumor necrosis factor-induced cytotoxicity. What we do understand and what we do not. FEBS 340, 9-16.

Boldin, M.P., Goncharov, T.M., Goltsev, Y.V., and Wallach, D. (1996). Involvement of $\mathrm{MACH}$, a novel MORT1/FADD-interacting protease, in Fas/APO-1 and TNF receptor-induced cell death. Cell 85 , 803-815.

Bornstein, P., McKinney, C.E., LaMarca, M.E., Winfield, S., Shingu, T., Devarayalu, S., Vos, H.L., and Ginns, E.I. (1995). Metaxin, a gene contiguous to both thrombospondin 3 and glucocerebrosidase, is required for embryonic development in the mouse: implications for Gaucher disease. Proc Natl Acad Sci U S A 92, 4547-4551.

Brekke, O.L., Shalaby, M.R., Sundan, A., Espevik, T., and Bjerve, K. S. (1992). Butylated hydroxyanisole specifically inhibits tumornecrosis factor-induced cytotoxicity and growth enhancement. Cytokine 4, 269-280.

Carswell, E.A., Old, L.J., Kassel, R.L., Green, S., Fiore, N., and Williamson, B. (1975). An endotoxin-induced serum factor that causes necrosis of tumors. Proc Natl Acad Sci U S A 72, 3666-3670.

Cho, Y.S., Challa, S., Moquin, D., Genga, R., Ray, T.D., Guildford, M., and Chan, F.K. (2009). Phosphorylation-driven assembly of the RIP1-RIP3 complex regulates programmed necrosis and virusinduced inflammation. Cell 137, 1112-1123.

Fiers, W., Beyaert, R., Declercq, W., and Vandenabeele, P. (1999). More than one way to die: apoptosis, necrosis and reactive oxygen damage. Oncogene 18, 7719-7730.

Galluzzi, L., Kepp, O., and Kroemer, G. (2009). RIP kinases initiate programmed necrosis. J Mol Cell Biol 1, 8-10.

Gardner, T. S. and Collins, J. J. (2000). Neutralizing noise in gene networks. Nature 405, 520-521.

Golstein, P., Ojcius, D.M., and Young, J.D. (1991). Cell death 
mechanisms and the immune system. Immunol Rev 121, 29-65.

Goossens, V., De Vos, K., Vercammen, D., Steemans, M., Vancompernolle, K., Fiers, W., Vandenabeele, P., and Grooten, J. (1999). Redox regulation of TNF signaling. Biofactors 10, 145-156.

Goossens, V., Grooten, J., De Vos, K., and Fiers, W. (1995). Direct evidence for tumor necrosis factor-induced mitochondrial reactive oxygen intermediates and their involvement in cytotoxicity. Proc Natl Acad Sci U S A 92, 8115-8119.

Gross, A., Pilcher, K., Blachly-Dyson, E., Basso, E., Jockel, J., Bassik, M.C., Korsmeyer, S.J., and Forte, M. (2000). Biochemical and genetic analysis of the mitochondrial response of yeast to $B A X$ and BCL-X(L). Mol Cell Biol 20, 3125-3136.

Harris, M.H., Vander Heiden, M.G., Kron, S.J., and Thompson, C.B. (2000). Role of oxidative phosphorylation in Bax toxicity. Mol Cell Biol 20, 3590-3596.

He, S., Wang, L., Miao, L., Wang, T., Du, F., Zhao, L., and Wang, X. (2009). Receptor interacting protein kinase-3 determines cellular necrotic response to TNF-alpha. Cell 137, 1100-1111.

Holler, N., Zaru, R., Micheau, O., Thome, M., Attinger, A., Valitutti, S., Bodmer, J.L., Schneider, P., Seed, B., and Tschopp, J. (2000). Fas triggers an alternative, caspase-8-independent cell death pathway using the kinase RIP as effector molecule. Nat Immunol 1, 489-495.

Janicke, R.U., Sprengart, M.L., Wati, M.R., and Porter, A.G. (1998). Caspase-3 is required for DNA fragmentation and morphological changes associated with apoptosis. J Biol Chem 273, 9357-9360.

Kmita, H. and Budzinska, M. (2000). Involvement of the TOM complex in external NADH transport into yeast mitochondria depleted of mitochondrial porin1. Biochim Biophys Acta 1509, 86-94.

Kroemer, G., Dallaporta, B., and Resche-Rigon, M. (1998). Themitochondrial death/life regulator in apoptosis and necrosis. Annu Rev Physiol 60, 619-642.

Kroemer, G. and Reed, J.C. (2000). Mitochondrial control of cell death. Nat Med 6, 513-519.

Kunz, J. and Hall, M.N. (1993). Cyclosporin A, FK506 and rapamycin: more than just immunosuppression. Trends Biochem Sci 18, 334-338.

$\mathrm{Li}, \mathrm{H}$. and Yuan, J. (1999). Deciphering the pathways of life and death. Curr Opin Cell Biol 11, 261-266.

Lin, Y., Choksi, S., Shen, H.M., Yang, Q.F., Hur, G.M., Kim, Y.S., Tran, J.H., Nedospasov, S.A., and Liu, Z.G. (2004). Tumor necrosis factor-induced nonapoptotic cell death requires receptor-interacting protein-mediated cellular reactive oxygen species accumulation. J Biol Chem 279, 10822-10828.

Liu, M.Y. and Colombini, M. (1992). Regulation of mitochondrial respiration by controlling the permeability of the outer membrane through the mitochondrial channel, VDAC. Biochim Biophys Acta 1098, 255-260.

Lotem, J., Kama, R., and Sachs, L. (1999). Suppression or induction of apoptosis by opposing pathways downstream from calciumactivated calcineurin. Proc Natl Acad Sci U S A 96, 12016-12020.

Marzo, I., Brenner, C., Zamzami, N., Jurgensmeier, J.M., Susin, S.A., Vieira, H.L., Prevost, M.C., Xie, Z., Matsuyama, S., Reed, J.C., and Kroemer, G. (1998). Bax and adenine nucleotide translocator cooperate in the mitochondrial control of apoptosis. Science 281, 2027-2031.

Minn, A.J., Velez, P., Schendel, S.L., Liang, H., Muchmore, S.W.,
Fesik, S.W., Fill, M., and Thompson, C.B. (1997). Bcl-x(L) forms an ion channel in synthetic lipid membranes. Nature 385, 353-357.

Muchmore, S.W., Sattler, M., Liang, H., Meadows, R.P., Harlan, J.E., Yoon, H.S., Nettesheim, D., Chang, B.S., Thompson, C.B., Wong, S.L., et al. (1996). X-ray and NMR structureof human Bcl-xL, an inhibitor of programmed cell death. Nature 381, 335-341.

Nadakavukaren, K.K., Nadakavukaren, J.J., and Chen, L.B. (1985). Increased rhodamine 123 uptake by carcinoma cells. Cancer Res 45, 6093-6039.

Neale, M.L., Fiera, R.A., and Matthews, N. (1988). Involvement of phospholipase A2 activation in tumour cell killing by tumour necrosis factor. Immunology $64,81-85$.

Old, L.J. (1985). Tumor necrosis factor (TNF). Science 230, 630-632.

Ono, K., Wang, X., and Han, J. (2001). Resistance to tumornecrosis factor-induced cell death mediated by PMCA4 deficiency. Mol Cell Biol 21, 8276-88.

Pastorino, J.G., Simbula, G., Yamamoto, K., Glascott, P.A.J., Rothman, R.J., and Farber, J.L. (1996). The cytotoxicity of tumor necrosis factor depends on induction of the mitochondrial permeability transition. J Biol Chem 271, 29792-29798.

Pfanner, N. and Geissler, A. (2001). Versatility of the mitochondrial protein import machinery. Nat Rev Mol Cell Biol 2, 339-349.

Ravagnan, L., Marzo, I., Costantini, P., Susin, S.A., Zamzami, N., Petit, P.X., Hirsch, F., Goulbern, M., Poupon, M.F., Miccoli, L., et al. (1999). Lonidamine triggers apoptosis via a direct, Bcl-2-inhibited effect on the mitochondrial permeability transition pore. Oncogene 18, 2537-2546.

Rothe, J., Gehr, G., Loetscher, H., and Lesslauer, W. (1992). Tumornecrosis factor receptors-structure and function. Immunol Res 11, 81-90.

Schnaitman, C. and Greenawalt, J.W. (1968). Enzymatic properties of the inner and outer membranes of rat liver mitochondria. J Cell Biol 38, 158-175.

Schulze-Osthoff, K., Bakker, A.C., Vanhaesebroeck, B., Beyaert, R., Jacob, W.A., and Fiers, W. (1992). Cytotoxic activity of tumor necrosis factor is mediated by early damage of mitochondrial functions. Evidence for the involvement of mitochondrial radical generation. J Biol Chem 267, 5317-5323.

Shimizu, S., Narita, M., and Tsujimoto, Y. (1999). Bcl-2 family proteins regulate the release of apoptogenic cytochrome $c$ by the mitochondrial channel VDAC. Nature 399, 483-487.

Strasser, A., O'Connor, L., and Dixit, V.M. (2000). Apoptosis signaling. Annu Rev Biochem 69, 217-245.

Tartaglia, L.A., Ayres, T.M., Wong, G.H., and Goeddel, D.V. (1993). A novel domain within the $55 \mathrm{kD}$ TNF receptor signals cell death. Cell 74, 845-853.

Tartaglia, L.A. and Goeddel, D.V. (1992). Two TNF receptors. Immunol Today 13, 151-153.

Tewari, M. and Dixit, V.M. (1995). Fas- and tumor necrosis factorinduced apoptosis ininhibited by the poxvirus crmA gene product. $J$ Biol Chem 270, 3255-3260.

Tracey, K.J. and Cerami, A. (1993). Tumor necrosis factor, other cytokines and disease. Annu Rev Cell Biol 9, 317-343.

Vander Heiden, M.G., Chandel, N.S., Li, X.X., Schumacker, P.T., Colombini, M., and Thompson, C.B. (2000). Outer mitochondrial membrane permeability can regulate coupled respiration and cell survival. Proc Natl Acad Sci US A 97, 4666-4671.

Vander Heiden, M.G. and Thompson, C.B. (1999). Bcl-2 proteins: 
regulators of apoptosis or of mitochondrial homeostasis? Nat Cell Biol 1, E209-216.

Vercammen, D., Beyaert, R., Denecker, G., Goossens, V., Van Loo, G., Declercq, W., Grooten, J., Fiers, W., and Vandenabeele, P. (1998). Inhibition of caspases increases the sensitivity of L929 cells to necrosis mediated by tumor necrosis factor. J Exp Med 187, 1477-1485.

Wang, X., Ono, K., Kim, S.O., Kravchenko, V., Lin, S.C., and Han, J. (2001). Metaxin is required for tumor necrosis factor-induced cell death. EMBO Rep 2, 628-633.
Yang, J., Liu, X., Bhalla, K., Kim, C.N., Ibrado, A.M., Cai, J., Peng, T.I., Jones, D.P., and Wang, X. (1997). Prevention of apoptosis by Bcl2: release of cytochrome $c$ from mitochondria blocked. Science 275, 1129-1132.

Zamzami, N. and Kroemer, G.(2001). The mitochondrion in apoptosis: how Pandora's box opens. Nat Rev Mol Cell Biol 2, 67-71.

Zhang, D.W., Shao, J., Lin, J., Zhang, N., Lu, B.J., Lin, S.C., Dong, M. Q., and Han, J. (2009). RIP3, an energy metabolism regulator that switches TNF-induced cell death from apoptosis to necrosis. Science 325, 332-336. 